\title{
Native Dreissena freshwater mussels in the Balkans: in and out of ancient lakes
}

\author{
T. Wilke ${ }^{1}$, R. Schulthei ${ }^{1}$, C. Albrecht ${ }^{1}$, N. Bornmann ${ }^{1}$, S. Trajanovski ${ }^{2}$, and T. Kevrekidis ${ }^{3}$ \\ ${ }^{1}$ Department of Animal Ecology \& Systematics, Justus Liebig University, Heinrich-Buff-Ring 26-32, IFZ, \\ 35392 Giessen, Germany \\ ${ }^{2}$ Hydrobiological Institute Ohrid, Naum Ohridski 50, 6000 Ohrid, Former Yugoslav Republic of Macedonia \\ ${ }^{3}$ Democritus University of Thrace, 68100 Alexandroupolis, Greece
}

Received: 14 May 2010 - Published in Biogeosciences Discuss.: 10 June 2010

Revised: 7 September 2010 - Accepted: 20 September 2010 - Published: 11 October 2010

\begin{abstract}
The Balkans is a biogeographically highly diverse region and a worldwide hotspot of endemic freshwater diversity. A substantial part of this diversity is attributed to well recognized and potential ancient lakes in its southwestern part. However, despite considerable research efforts, faunal relationships among those lakes are not well understood. Therefore, genetic information from native representatives of the mussel genus Dreissena is here used to test the biogeographical zonation of the southwestern Balkans, to relate demographic changes to environmental changes, to assess the degree of eco-insularity, to reconstruct their evolutionary history, and to explore the potential of native taxa for becoming invasive.

Phylogeographical and population genetic analyses indicate that most studied populations belong to two native species: D. presbensis (including the distinct genetic subgroup from Lake Ohrid, "D. stankovici") and D. blanci. In addition, the first confirmed record of invasive $D$. polymorpha in the southwestern Balkan is presented.

The distribution of native Dreissena spp. generally coincides with the biogeographical zonations previously suggested based on fish data. However, there is disagreement on the assignment of the ancient lakes in the area to respective biogeographical regions. The data for Lake Ohrid are not conclusive. A closer biogeographical connection to lakes of the Vardar region and possibly the northern Ionian region is, however, suggested for Lake Prespa.

The reconstruction of the evolutionary history of Dreissena spp. suggests that populations underwent demographic and spatial expansions in the recent past. Expansions
\end{abstract}

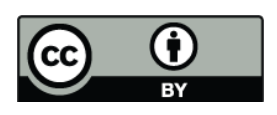

Correspondence to: T. Wilke (tom.wilke@allzool.bio.uni-giessen.de) started around 320 000-300 000 years ago in "D. stankovici", $160000-140000$ years ago in D. blanci, and 110 000-70 000 years ago in $D$. presbensis. These time frames are discussed within the context of available paleogeological data for lakes Ohrid and Prespa. It is suggested that regional environmental changes may have had pronounced effects on the population histories of native Dreissena spp., though the high buffer capacity of Lake Ohrid may have lessened these effects in " $D$. stankovici". In addition, local events influencing individual lakes had very likely considerable effects on the demographic histories of Dreissena spp. as well. The observed patterns of immigration and emigration in and out of ancient lakes may suggest that limited gene flow enabled the survival of few isolated subpopulations and that later on eco-insularity (selective advantages of locally adopted groups) may have prevented excessive hybridization and sympatry of closely related taxa.

As for the potential invasiveness of native Dreissena spp., the inferred spatial expansions are not human-mediated and all taxa still appear to be restricted to their native ranges. A concern, however, is that today $D$. presbensis and D. blanci also occur in artificial water bodies, and that invasive $D$. polymorpha has reached the area.

\section{Introduction}

The Balkans, a mountainous area in southeastern Europe, have long been recognized as a worldwide hotspot of endemic freshwater biodiversity (Radoman, 1985; Banarescu, 1991; Griffiths et al., 2004; Strong et al., 2008). The high degree of biodiversity, particularly in invertebrates, has been attributed to (i) the role of the Balkans as one of

Published by Copernicus Publications on behalf of the European Geosciences Union. 


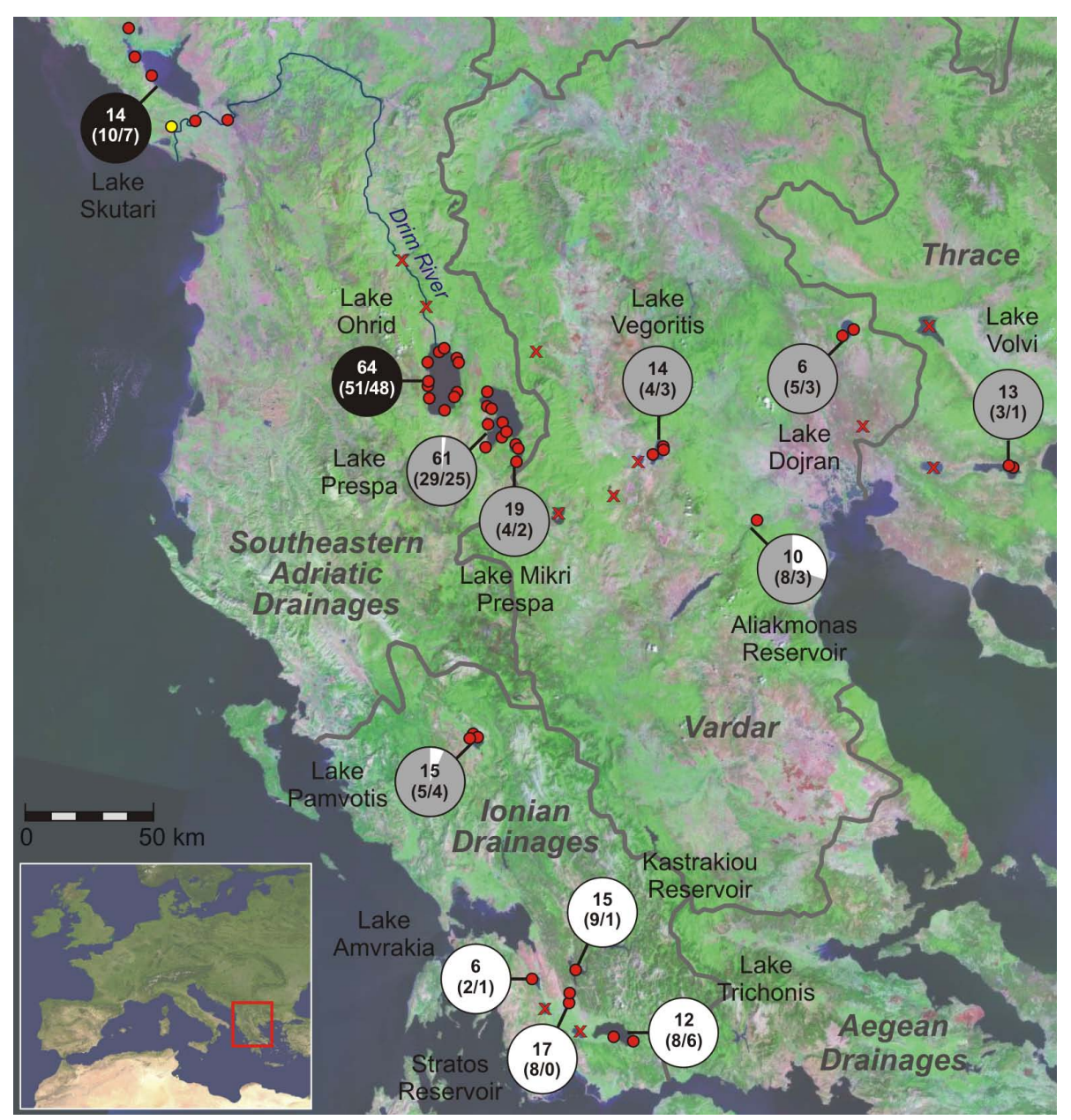

Fig. 1. Map of the southwestern Balkans showing the water bodies sampled for Dreissena spp. Records for native species are shown as red dots, for invasive species as yellow dot (for detailed locality information see Table 1). Negative records of Dreissena spp. are indicated by the x-symbol. Distribution of genetic groups of native species within the water bodies studied are indicated by coloured pie charts (black: "D. stankovici", grey: D. presbensis, white: D. blanci). Note that this assignment is a result of the present study. Numbers indicate total number of specimens studied from each water body (upper line) as well as the total number of haplotypes/private haplotypes found (lower line in parentheses). Major ecoregions are derived from Abell et al. (2008) and indicated by solid grey lines and italic names. Base map adapted from Mountain High Maps ${ }^{\circledR},{ }^{\circledR}$ 1993, Digital Wisdom ${ }^{\circledR}$, Inc.

the major European Pleistocene refugia (e.g. Denèfle et al., 2000; Tzedakis, 2009; Lézine et al., 2010), (ii) its rich geological history, for example, the upheaval of various mountain ranges, the interplay of Tethys and Paratethys, and the former contact to Anatolia (Radoman, 1985; Banarescu, 1991), (iii) its various biogeographical zones (Banarescu, 2004), and (iv) its high diversity of freshwater habitats ranging from cold springs, glacial lakes and mountain streams to ephemeral rivers and extended lake systems, including a number of actual or potential ancient lakes. In fact, the southwestern Balkans arguably are home to all the ancient lakes in Europe, except for the Caspian Sea (Albrecht and Wilke, 2008; also see Fig. 1).

These lakes comprise ancient Lake Ohrid, situated in the Former Yugoslav Republic of Macedonia (from hereon called Macedonia) and the Republic of Albania (from hereon called Albania), as well as Lake Prespa (Macedonia, Greece, Albania). In addition, there are less known, potential ancient lakes such as lakes Skutari (Montenegro, Albania), Mikri Prespa (Greece, Albania), Pamvotis (Greece), Vegoritis (Greece), Dojran (Macedonia, Greece), and Trichonis (Greece). As ancient lakes have often existed continuously for hundred thousand or even millions of years, and as they can harbour a high degree of endemic faunal elements, they are popular systems for reconstructing faunal relationships and changes in species composition in space and time (e.g. Martens, 1997).

There is only limited knowledge of the latter factor for the Balkan ancient lakes, thus hampering a better understanding of the link between geography and faunal evolution of 
lacustrine faunas in the Balkans in general. Parts of the problem are uneven scientific coverage of the different water bodies in the area with a strong bias to the ancient lakes Ohrid and Prespa (reviewed in Albrecht and Wilke, 2008) and, to a lesser extent, to lakes Trichonis (e.g. Albrecht et al., 2009), Pamvotis (e.g. Frogley and Preece, 2004), Skutari (e.g. Karaman and Beeton, 1981), and Dojran (e.g. Griffiths et al., 2002; Reed, 2004). More importantly, despite recent attempts to enhance our understanding of biogeographical processes on a regional scale (Griffiths and Frogley, 2004; Korniushin, 2004; Lipej and Dulčić, 2004; Reed, 2004; Hauswald et al., 2008), our knowledge of patterns of freshwater biogeographical zones in the Balkans remains largely biased towards fish and drainage networks (e.g. Banarescu, 2004). According to these authors, the southwestern Balkans are bordered by the Danube River Basin to the north and by the Adriatic Sea, the Mediterranean Sea and the Aegean Sea to the west, south and east, respectively. The southwestern Balkans themselves consist of the following biogeographical regions: the Dalmatian region in the northwest, the Macedonia-Thessaly region in the north, the south AdriaticIonian region in the west, the Thrace region in the northeast, as well as the Attiko-Beotia region in the southeast. This zoogeographical division largely corresponds to the "ecoregions" suggested by Abell et al. (2008) (see Fig. 1).

Despite minor differences in the corresponding regions, both divisions place lakes Ohrid and Prespa in the southeastern Adriatic Drainage/south Adriatic-Ionian region. Banarescu (1991: 751), however, specifically acknowledged the faunal distinctness of Lake Ohrid "... its fauna has however a number of peculiarities and cannot be considered as only a subdivision of the large West Balkan ...”.

The affiliation of both lakes to the southeastern Adriatic drainage region, and particularly the close biogeographical relationships between the two lakes remains controversial (reviewed in Albrecht and Wilke, 2008). In fact, a cluster analysis of 147 mollusc species from all major natural lakes in the southwestern Balkans (Albrecht et al., 2009) indicated that Lake Ohrid is highly distinct with relatively little faunal overlap to neighbouring Lake Prespa. The latter appears to be more closely related to lakes of the Vardar region (lakes Vegoritis and Dojran), and not to the lakes of the southeastern Adriatic and Ionian drainages (lakes Skutari, Pamvotis, Amvrakia, Trichonis; but see Albrecht et al., 2008).

So far, there is no conclusive explanation for the low degree of faunal exchange between Lake Ohrid and neighbouring water systems. Radoman (1985) suggested an inherent structure of the biocoenosis that prevents such events; the well adapted endemic organisms of Lake Ohrid may outcompete most invading species but are probably inferior outside native Lake Ohrid - a pattern sometimes referred to as eco-insularity (e.g. Albrecht and Wilke, 2008).

In the recent past, a number of molecular studies have used species-level phylogenetic relationships as indirect evidence for faunal exchange of Lake Ohrid with neighbouring water bodies (e.g. Albrecht et al., 2006, 2007, 2008; Wilke et al., 2007; Hauswald et al., 2008; Schultheiß et al., 2008; Wysocka et al., 2008; Trajanovski et al., 2010). In contrast, population-genetic studies remain scarce (e.g. Sell and Spirkovski, 2004).

The problem is circular: to study immigration and emigration in ancient lakes within a population-level context a single species or a set of closely related species with a Balkanwide distribution would ideally be required. However, due to the high degrees of endemism in these ancient lakes with corresponding low levels of immigration and emigration, few such candidate species exist.

A potential exception are the closely related southwestern Balkan representatives of the freshwater mussel genus Dreissena (Van Beneden, 1835).

The genus has become infamous because of two highly invasive representatives, the zebra mussel $D$. polymorpha (Pallas, 1771) and the quagga mussel D. rostriformis bugensis (Andrusov, 1897), which are considered pest species in large parts of North America (e.g. May and Marsden, 1992; Nalepa and Schloesser, 1993) and Europe (e.g. Kinzelbach, 1992; Molloy et al., 2007). Though the occurrence of at least one of these invasive species, D. polymorpha, in the southwestern Balkans has been noted repeatedly (reviewed in Albrecht et al., 2007), recent studies strongly suggest that, so far, only native species of Dreissena occur in the area (e.g. Stepien et al., 2003; Gelembiuk et al., 2006; May et al., 2006; Albrecht et al., 2007; Molloy et al., 2010). Albrecht et al. (2007) showed that these native representatives are closely related, all belonging to the subgenus Carinodreissena. The southern parts of the area are inhabited by $D$. blanci Westerlund, 1890, which has originally been described from the Lake Trichonis area. The authors also showed that the second native species, nominal $D$. stankovici, L'vova and Starobogatov, 1982, supposedly endemic to Lake Ohrid, is not restricted to the ancient lakes Ohrid and Prespa, but that it is a widespread taxon in the northern part of the area. As nominal D. blanci f. presbensis Kobelt, 1915 described from Lake Prespa has nomenclatural priority over $D$. stankovici described from Lake Ohrid, the correct name for the latter taxon should be Dreissena presbensis. However, for strictly didactical reasons, we here use the name $D$. stankovici for the genetic subgroup primarily associated with Lake Ohrid, and $D$. presbensis for the genetic subgroup primarily associated with Lake Prespa. Interestingly, specimens of D. blanci and $D$. presbensis occur sympatrically in lakes Prespa and Pamvotis.

Given the close relationship of native Balkan Dreissena spp. and their relatively wide distribution, here we utilize genetic information from 269 specimens within a system of phylogeographical and population genetic analyses to:

- test the biogeographical zones in the southwestern Balkans with respect to the regions previously described in the area, 
- investigate the relationship between demographic changes in Dreissena spp. and environmental changes,

- assess the degree of eco-insularity and reconstruct the evolutionary history of Dreissena spp., and

- explore the potential of these native taxa for becoming invasive.

\section{Materials and methods}

\subsection{Specimens studied}

The current study includes samples of Dreissena spp. from 47 localities (Table 1) in the central and southwestern Balkans, covering 13 larger natural and artificial water bodies (important limnological characteristics of natural lakes are given in Table 2). In addition, 11 other major water bodies were sampled, but did not yield specimens of Dreissena spp.: the Mavrovo, Globocica, and Strezevo reservoirs (Macedonia); lakes Kastorias, Petron, Chimaditis, Pikrolimni, Koronia, Lysimachia, and Ozeros, as well as the Kerkini Reservoir (all Greece). Field work was conducted between 2003 and 2009.

Our sampling encompasses all nominal Dreissena taxa from the area (see Bank, 2006; Albrecht et al., 2007), including materials from or close to their respective type localities: D. stankovici L'vova and Starobogatov, 1982 (type locality Lake Ohrid), D. blanci Westerlund, 1890 (=D. chemnitzi Westerlund and Blank, 1879; =D. hellenica Locard, 1893; $=D$. thiesae Locard, 1893; type localities all Missolonghi), and D. blanci presbensis Kobelt, 1915 (type locality Lake Prespa).

\subsection{DNA isolation and sequencing}

The method described by Wilke et al. (2006) was used for isolating DNA from individual mussels. The primers for amplifying a fragment of the cytochrome $c$ oxidase subunit I (COI) gene with a target length of 658 base pairs (bp), excluding $51 \mathrm{bp}$ of primer sequence, were LCO1490 and HCO2198, as described by Folmer et al. (1994). Sequences (forward and reverse) were determined using the LI-COR (Lincoln, NE, USA) DNA sequencer Long ReadIR 4200 and the Thermo Sequenase fluorescent labelled primer cycle sequencing kit (Amersham Pharmacia Biotech, Piscataway, NJ, USA). The protein-coding mitochondrial COI sequences, which in Dreissena are free of insertions and deletions, were aligned unambiguously by eye using BioEdit 7.0.8.0 (Hall, 1999). The first few base pairs behind the $3^{\prime}$ end of each primer were difficult to read. We therefore uniformly cut off the first and last $10 \mathrm{bp}$ of each sequence, leaving a 638-bplong overlapping fragment for the COI gene. All sequences are available from GenBank (accession numbers EF414478EF414492, EF414496, HM209829-HM210081).

\subsection{Phylogeographical history and summary statistics}

\subsubsection{Network analyses}

A statistical parsimony haplotype network was constructed utilizing the program TCS 1.21 (Clement et al., 2000), with the connection limit set to $95 \%$ and gaps being treated as fifth state. Network ambiguities were resolved according to the criteria of Pfenninger and Posada (2002). In a second analysis, we reduced the connection limit to $90 \%$ (= $15 \mathrm{mu}$ tational steps) in an attempt to infer the connections among sub-networks. In a third analysis, we analyzed our three taxa individually to infer the respective ancestral haplotypes.

\subsubsection{Test for genetic structure}

To reconstruct the demographic and spatial history of Dreissena spp., we first tested for significant genetic structure within those taxa that did not exceed the $95 \%$ connection limit of the network analysis (see Result section).

We performed a hierarchical Analysis of Molecular Variance (AMOVA) with a distance matrix of pairwise differences and tested the significance of the $\Phi$ statistic by generating a null-distribution based on 10000 permutations of the original dataset utilizing Arlequin 3.5.1.2. (Excoffier et al., 2005). The hierarchical grouping variables were (i) taxa, (ii) lake systems, (iii) populations.

As an alternative approach for studying genetic differentiation among taxa, we performed an exact test as suggested by Raymond and Rousset (1995) and implemented in $\mathrm{Ar}$ lequin 3.5.1.2. The assumed null hypothesis of the test statistics is a random distribution of different haplotypes among populations (i.e. panmixia). The significance of differentiation between taxa was evaluated by running the Markov chain for 1000000 steps.

\subsubsection{Tests for neutrality}

In order to test for the effects of past demographic events (i.e. changes in population size) or influences of selection in Dreissena spp., we utilized Tajima's (1989) $D$ statistic as implemented in Arlequin 3.5.1.2. The significance of the statistics was inferred using coalescent simulations with 10000 replicates.

\subsubsection{Testing models of demographic and spatial expansions}

Demographic and spatial histories of populations were inferred by linking the amount and distribution of sequence differences to relative time since divergence, utilizing mismatch analyses. While a demographic equilibrium, that is, constant population size, generates a multimodal distribution of pairwise nucleotide differences, a demographic expansion is indicated by a unimodal distribution (Rogers and Harpending, 1992). Schneider and Excoffier (1999) and Excoffier (2004) 
Table 1. Locality information of studied specimens of Dreissena spp., including drainage system, latitude and longitude information (in decimal degrees $\mathrm{N}$ and $\mathrm{W}$, respectively), as well as DNA isolation numbers and respective haplotype information for individual specimens (in parentheses).

\begin{tabular}{|c|c|c|c|}
\hline Drainage system & Latitude & Longitude & DNA isolation number of individual specimens (haplotype number) \\
\hline \multicolumn{4}{|l|}{ Dreissena polymorpha } \\
\hline Skutari (Saško Lake) & 41.97679 & 19.33871 & $12852(\mathrm{Pol}), 12853(\mathrm{Pol}), 12855(\mathrm{Pol})$ \\
\hline \multicolumn{4}{|l|}{ Dreissena "stankovici" } \\
\hline Ohrid & 41.10508 & 20.78048 & 3960 (S7), 4157 (S9), 4158 (S1), 4189 (S13), 4190 (S14), 4654 (S34) \\
\hline Ohrid & 41.16074 & 20.68662 & 4159 (S10), 4191 (S1), 4192 (S15), 4249 (S21), 4287 (S25), 4288 (S26) \\
\hline Ohrid & 41.16267 & 20.68716 & 4294 (S29), 4295 (S30), 4296 (S32), 4297 (S32), 4298 (S33) \\
\hline Ohrid & 41.11485 & 20.64473 & 3961 (S8), 4161 (S5), 4162 (S11), 4193 (S16), 4194 (S17), 4663 (S3), 4664 (S36) \\
\hline Ohrid & 41.08714 & 20.79424 & 4163 (S12), 4164 (S3), 4195 (S18), 4291 (S28), 4657 (S35), 4658 (S3) \\
\hline Ohrid & 41.01626 & 20.63430 & 4701 (S37), 4702 (S38), 4703 (S39), 4704 (S40), 4705 (S6), 4706 (S41) \\
\hline Ohrid & 40.97324 & 20.78668 & 4171 (S2), 4172 (S1), 4203 (S19), 4204 (S20), 4289 (S5), 4290 (S27) \\
\hline Ohrid & 40.91363 & 20.73756 & 4911 (S51), 4912 (S52), 4914 (S53), 4916 (S4), 4917 (S54), 4918 (S5) \\
\hline Ohrid & 40.97301 & 20.64445 & 4895 (S46), 4896 (S6), 4897 (S47) \\
\hline Ohrid & 41.03023 & 20.63521 & 4887 (S1), 4888 (S42), 4889 (S43), 4891 (S3), 4892 (S44), 4893 (S45) \\
\hline Ohrid & 40.98652 & 20.79818 & 3967 (S2), 4281 (S22), 4282 (S23), 4283 (S24), 4284 (S1), 4285 (S2), 4286 (S2) \\
\hline Skutari & 42.23 & 19.13 & 4903 (S4), 4905 (S4), 4906 (S4), 4908 (S48), 4909 (S49), 4910 (S50) \\
\hline Skutari & 42.35862 & 19.10630 & 12845 (S6) \\
\hline Skutari & 42.16695 & 19.22564 & 12847 (S25), 12849 (S58), 12850 (S56) \\
\hline Skutari & 41.98523 & 19.43216 & $12833(\mathrm{~S} 57), 12834(\mathrm{~S} 25)$ \\
\hline Skutari & 42.00598 & 19.60028 & 12835 (S55), 12838 (S6) \\
\hline \multicolumn{4}{|l|}{ Dreissena presbensis } \\
\hline Aliakmonas & 40.48620 & 22.25767 & 9185 (P8), 9186 (P2), 9188 (P9), 9189 (P43), 9191 (P44), 9192 (P9), 9193 (P4) \\
\hline Dojran & 41.21873 & 22.77928 & $4571(\mathrm{P} 24)$ \\
\hline Dojran & 41.18786 & 22.72310 & 9304 (P8), 9306 (P2), 9307 (P45), 9308 (P46), 9313 (P2) \\
\hline Mikri Prespa & 40.75589 & 21.10273 & 4469 (P14), 4470 (P1), 4471 (P1), 4473 (P1), 4474 (P15) \\
\hline Mikri Prespa & 40.69718 & 21.03827 & 4475 (P1), 4478 (P1), 4479 (P1), 4480 (P1) \\
\hline Mikri Prespa & 40.79296 & 21.07416 & 4481 (P1), 4482 (P1), 4483 (P1), 4485 (P1), 4486 (P1) \\
\hline Mikri Prespa & 40.69718 & 21.03827 & $4647(\mathrm{P} 1), 4649(\mathrm{P} 1)$ \\
\hline Mikri Prespa & 40.79296 & 21.07416 & $4650(\mathrm{P} 6), 4651(\mathrm{P} 1)$ \\
\hline Mikri Prespa & 40.75589 & 21.10273 & $4652(\mathrm{P} 1)$ \\
\hline Pamvotis & 39.68320 & 20.86954 & 4575 (P3), 4661 (P3), 4662 (P3) \\
\hline Pamvotis & 39.68872 & 20.84427 & 4642 (P3), 4643 (P3), 4644 (P3), 4645 (P3), 4646 (P25) \\
\hline Pamvotis & 39.67827 & 20.87722 & 4683 (P28), 4684 (P5), 4685 (P3), 4686 (P3), 4687 (P3), 4688 (P29) \\
\hline Prespa & 40.87103 & 20.98772 & 3966 (P10), 4275 (P1), 4276 (P1), 4277 (P1), 4278 (P13), 4280 (P1) \\
\hline Prespa & 40.93665 & 20.94414 & 3964 (P1), 4165 (P1), 4166 (P1), 4167 (P11), 4197 (P1), 4198 (P1), 4199 (P12) \\
\hline Prespa & 40.93828 & 20.94855 & 4168 (P1), 4169 (P1), 4170 (P1), 4200 (P1), 4201 (P1), 4202 (P1) \\
\hline Prespa & 40.76848 & 20.92642 & $\begin{array}{l}4813 \text { (P1), } 4814 \text { (P30), } 4815 \text { (P1), } 4816 \text { (P31), } 4817 \text { (P7), } 4818 \text { (P32), } 4829 \text { (P6), } \\
4830 \text { (P1), } 4831 \text { (P1), } 4832 \text { (P1), } 4833 \text { (P34), } 4834 \text { (P1) }\end{array}$ \\
\hline Prespa & 40.86210 & 20.94061 & $\begin{array}{l}4821 \text { (P7), } 4822 \text { (P1), } 4823 \text { (P1), } 4824 \text { (P1), } 4826 \text { (P1), } 4827 \text { (P33), } 4839 \text { (P1), } \\
4840 \text { (P35), } 4841 \text { (P1), } 4842 \text { (P36), } 4843 \text { (P37), } 4844 \text { (P38) }\end{array}$ \\
\hline Prespa & 40.99446 & 20.93346 & 4845 (P39), 4846 (P1), 4847 (P1), 4848 (P40), 4849 (P41), 4850 (P1) \\
\hline Prespa & 40.82032 & 21.01939 & 4503 (P5), 4505 (P16), 4506 (P5), 4507 (P17), 4510 (P18) \\
\hline Prespa & 40.83677 & 21.02141 & 4511 (P1), 4512 (P19), 4514 (P20), $4515(\mathrm{P} 21), 4516(\mathrm{P} 22), 4518$ (P23) \\
\hline Vegoritis & 40.71857 & 21.74950 & $4572(\mathrm{P} 2), 4573(\mathrm{P} 2), 4574(\mathrm{P} 2)$ \\
\hline Vegoritis & 40.78619 & 21.81685 & 4665 (P26), 4666 (P2), 4667 (P27), 4668 (P2) \\
\hline Vegoritis & 40.79 & 21.82 & $5169(\mathrm{P} 42), 5171(\mathrm{P} 2), 5172(\mathrm{P} 2), 5201(\mathrm{P} 2), 5203(\mathrm{P} 2), 5204(\mathrm{P} 2), 5205(\mathrm{P} 2)$ \\
\hline Volvi & 40.67561 & 23.56736 & $\begin{array}{l}9264 \text { (P4), } 9265 \text { (P2), } 9266 \text { (P2), } 9267 \text { (P2), } 9268 \text { (P2), } 9269 \text { (P4), } \\
9270 \text { (P4), } 9271 \text { (P2), } 9272 \text { (P2), } 9273 \text { (P2) }\end{array}$ \\
\hline Volvi & 40.67565 & 23.56322 & 9314 (P47), 9316 (P2), 9317 (P2) \\
\hline \multicolumn{4}{|l|}{ Dreissena blanci } \\
\hline Aliakmonas & 40.48620 & 22.25767 & 9184 (B1), 9187 (B2), 9190 (B2) \\
\hline Amvrakia & 38.76788 & 21.16916 & 4790 (B3), 4791 (B3), 4793 (B5), 4794 (B3), 4795 (B3), 4796 (B3) \\
\hline Kastrakiou & 38.82002 & 21.33194 & $\begin{array}{l}9164 \text { (B1), } 9165 \text { (B6), } 9166 \text { (B7), } 9167 \text { (B8), } 9168 \text { (B2), } 9169 \text { (B4), } 9170 \text { (B1), } \\
9171 \text { (B6), } 9172 \text { (B9), } 9173 \text { (B8), } 9274 \text { (B2), } 9275 \text { (B17), } 9276 \text { (B5), } 9277 \text { (B6), } \\
9279 \text { (B1) }\end{array}$ \\
\hline Pamvotis & 39.68320 & 20.86954 & 4576 (B10) \\
\hline Prespa & 40.82032 & 21.01939 & 4508 (B1) \\
\hline Stratos & 38.67126 & 21.34027 & $\begin{array}{l}9174 \text { (B1), } 9175 \text { (B4), } 9176 \text { (B17), } 9177 \text { (B2), } 9178 \text { (B5), } 9179 \text { (B9), } 9180 \text { (B1), } \\
9181 \text { (B4), } 9182 \text { (B1), } 9183 \text { (B7), } 9678 \text { (B4), } 9679 \text { (B2), } 9680 \text { (B4), } 9681 \text { (B5), } \\
9682 \text { (B5), } 9684 \text { (B9), } 9685 \text { (B6) }\end{array}$ \\
\hline Trichonis & 38.55133 & 21.53817 & 4773 (B2), 4775 (B11), 4776 (B12), 4777 (B13), 4778 (B2), 4779 (B14) \\
\hline Trichonis & 38.52763 & 21.65608 & 4781 (B2), 4782 (B15), 4784 (B1), 4785 (B16), 4787 (B2), 4788 (B1) \\
\hline
\end{tabular}


Table 2. Summarized physiographical and hydrological characteristics of large natural lakes in the southwestern Balkans from which specimens of Dreissena spp. were obtained.

\begin{tabular}{lccccccccc}
\hline & $\begin{array}{c}\text { Lake } \\
\text { Ohrid }^{1}\end{array}$ & $\begin{array}{c}\text { Lake } \\
\text { Skutari }^{2}\end{array}$ & $\begin{array}{c}\text { Lake } \\
\text { Prespa }^{1}\end{array}$ & $\begin{array}{c}\text { Lake } \\
\text { Trichonis }^{3}\end{array}$ & $\begin{array}{c}\text { Lake } \\
\text { Vegoritis }^{3}\end{array}$ & $\begin{array}{c}\text { Lake } \\
\text { Volvi }^{3}\end{array}$ & $\begin{array}{c}\text { Lake } \\
\text { Mikri }_{\text {Prespa }^{1}}\end{array}$ & $\begin{array}{c}\text { Lake } \\
\text { Dojran }^{3}\end{array}$ & $\begin{array}{c}\text { Lake } \\
\text { Pamvotis }^{3}\end{array}$ \\
\hline Altitude (m a.s.l.) & 693 & 10 & 849 & 18 & 524 & 37 & 853 & 145 & 470 \\
Amvrakia $^{3}$ \\
Surface area (km
\end{tabular}

${ }^{1}$ Albrecht and Wilke, 2008; ${ }^{2}$ Royal Haskoning, 2006; ${ }^{3}$ Zacharias et al., 2002; length and width calculated from GoogleEarth ${ }^{\circledR} 2010$ Google.

extended this approach, allowing the estimation of demographic parameters from demographic and spatial expansion models based on a generalized non-linear least-square approach.

First, we tested the spatial expansion model for the three taxa Dreissena "stankovici", D. presbensis, and D. blanci. In contrast to the demographic expansion model, this model does not require panmixia but assumes that the sampled group is subdivided into an infinite number of demes exchanging migrants (i.e. restricted gene flow between groups). Then, we tested the model of demographic expansion in each of the three taxa. This model requires panmixia and as this assumption was violated in all taxa due to a significant genetic structuring of individual lakes in the AMOVA (except for " $D$. stankovici"), we only used specimens from that lake system that presumably constitutes the source for subsequent spatial expansion of the respective taxon for this test (see Results section for details). For " $D$. stankovici" this is Lake Ohrid, for D. presbensis Lake Prespa, and for D. blanci Lake Trichonis. Confidence intervals (CI) for both models were estimated based on coalescent simulations with 10000 replicates.

\subsubsection{Estimation of time since population expansion}

Mismatch analyses also allow for estimating $\tau$, a population parameter that enables the calculation of time since expansion. With $\tau=2 t u, t$ is the time in generations and $u$ is the total mutation rate over all nucleotide positions (Rogers and Harpending, 1992; Schneider and Excoffier, 1999). In the absence of a Dreissena-specific substitution rate for the COI gene, we used the trait specific COI Protostomia molecular clock rate of $1.22 \% \pm 0.27 \%$ substitutions per site and one million years for the Jukes-Cantor model (Wilke et al., 2009). This rate has been shown to be robust among invertebrate taxa with similar biological and life-history characteristics (i.e. dioeceous tropical or subtropical taxa with a generation time of $\sim 1$ year and a body size of approximately $2-50 \mathrm{~mm}$ ). These criteria are met by Dreissena spp. from the Balkans.

To provide meaningful confidence intervals for our time estimates, we here account for both the error of the $\tau$ estimate $(\Delta \tau$; see Result section) and the error of the substitution rate ( $\Delta \mu$, here $0.27 \% \mathrm{Ma}^{-1}$, see above) by calculating the propagation of uncertainty following the approach of Schultheiß et al. (2010).

\section{Results}

\subsection{Network analyses}

The first analysis showed three distinct sub-networks that exceeded the 95\% connection limit. Sub-network I comprises all haplotypes of native Dreissena presbensis, including those of "D. stankovici", sub-network II all haplotypes of native $D$. blanci, and sub-network III the single haplotype of invasive D. polymorpha (Fig. 2).

The D. blanci sub-network consists of 55 specimens with 17 haplotypes, 10 of them shared (Fig. 2). According to the network analysis, the taxon occurs allopatrically in the southern water bodies Trichonis, Amvrakia, Stratos and Kastrakiou, and, in low frequencies, sympatrically with $D$. presbensis in the central lakes Pamvotis and Prespa as well as in the Aliakmonas Reservoir (Fig. 1). The highest haplotype diversity and the highest ratio of private haplotypes (i.e. haplotypes only occurring in a single water body) are found in Lake Trichonis.

The D. presbensis/“D. stankovici" sub-network encompasses 211 specimens with 105 haplotypes (58 for "D. stankovici" and 47 for D. presbensis), 16 of them shared (7 and 9, respectively).

Haplotypes of "D. stankovici" (lakes Ohrid and Skutari) are completely separate from $D$. presbensis haplotypes from lakes Pamvotis, Prespa, Mikri Prespa, Vegoritis, Dojran, and 


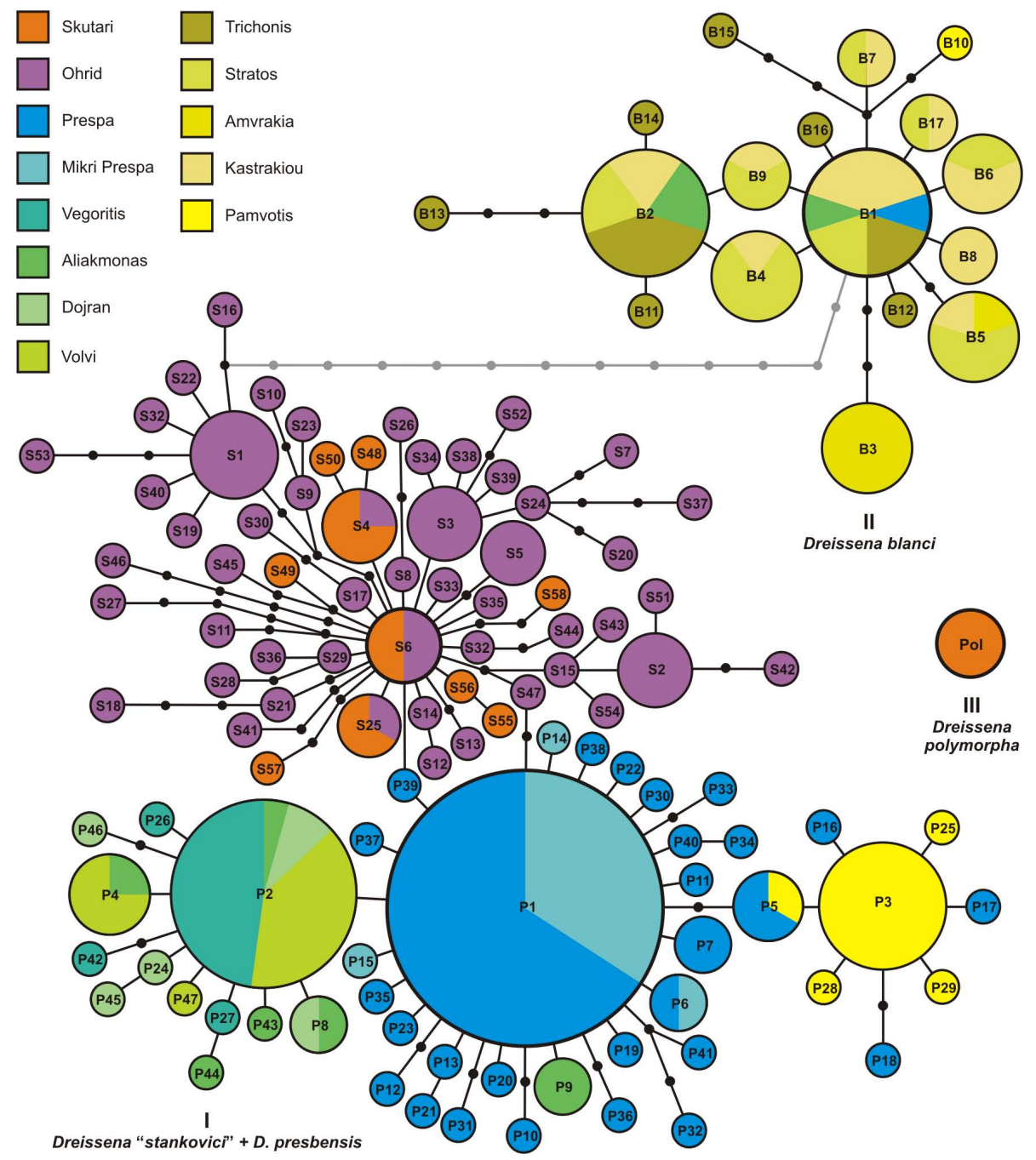

Fig. 2. Statistical parsimony haplotype network of Dreissena spp. based on COI mtDNA data (connection limit 95\%). Haplotypes are colourcoded according to major lake systems (see Table 1 for detailed locality information). Areas of circles representing the haplotypes found are proportional to the number of specimens sharing the respective haplotype (for an assignment of haplotypes to individual specimens and their exact locations see Table 1; $\mathrm{Pol}=D$. polymorpha, $\mathrm{S}=$ "D. stankovici", $\mathrm{P}=$ D. presbensis, $\mathrm{B}=D$. blanci). Missing haplotypes are indicated by black dots. The grey line shows the connection between " $D$. stankovici" and $D$. blanci when the TCS connection limit is reduced to $90 \%$. Haplotypes with the highest probability of being the ancestral haplotypes in the four taxa studied are indicated by bold circles (see Method section for details).

Volvi as well as the Aliakmonas Reservoir (Figs. 1 and 2). The two groups are, however, separated by only one mutational step. The highest haplotype diversity and the highest ratio of private haplotypes for "D. stankovici" are to be found in Lake Ohrid; for D. presbensis in Lake Prespa.

When the connection limit of the network analysis is reduced to $90 \%$ in order to infer the link between subnetworks, an almost direct connection between the most common haplotype in "D. stankovici" (haplotype S1 in Fig. 2) and the most common haplotype in D. blanci (B1) becomes evident. However, the D. polymorpha sub-network remains disconnected.
The individual network analyses of the three native taxa suggested the following ancestral haplotypes: "D. stankovici", haplotype S6 (biggest outgroup probability 0.127$) ; D$. presbensis, haplotype P1 (biggest outgroup probability 0.116 ); D. blanci, haplotype B1 (biggest outgroup probability 0.256 ).

The potential ancestral haplotype in "D. stankovici" (S6) constitutes a central haplotype within this taxon and it is shared by specimens from lakes Ohrid and Skutari. Lake Ohrid, however, is considered to be the ancestral area for the extant haplotypes of "D. stankovici" as it has a higher diversity of haplotypes and a higher percentage of private haplotypes (Fig. 1). The putative ancestral haplotype for 
Table 3. Results of exact test for significant pairwise genetic differences (level 0.05) in Dreissena presbensis from different water bodies.

\begin{tabular}{|c|c|c|c|c|c|c|}
\hline & $\begin{array}{l}\text { Lake } \\
\text { Prespa }\end{array}$ & $\begin{array}{c}\text { Lake Mikri } \\
\text { Prespa }\end{array}$ & $\begin{array}{c}\text { Lake } \\
\text { Pamvotis }\end{array}$ & $\begin{array}{c}\text { Lake } \\
\text { Vegoritis }\end{array}$ & $\begin{array}{c}\text { Lake } \\
\text { Dojran }\end{array}$ & $\begin{array}{l}\text { Lake } \\
\text { Volvi }\end{array}$ \\
\hline $\begin{array}{l}\text { Lake } \\
\text { Prespa }\end{array}$ & & & & & & \\
\hline $\begin{array}{l}\text { Lake } \\
\text { Mikri } \\
\text { Prespa }\end{array}$ & + & & & & & \\
\hline $\begin{array}{l}\text { Lake } \\
\text { Pamvotis }\end{array}$ & + & + & & & & \\
\hline $\begin{array}{l}\text { Lake } \\
\text { Vegoritis }\end{array}$ & + & + & + & & & \\
\hline $\begin{array}{l}\text { Lake } \\
\text { Dojran }\end{array}$ & + & + & - & + & & \\
\hline $\begin{array}{l}\text { Lake } \\
\text { Volvi }\end{array}$ & + & + & + & + & + & \\
\hline $\begin{array}{l}\text { Aliakmonas } \\
\text { Reservoir }\end{array}$ & + & + & - & + & - & + \\
\hline
\end{tabular}

D. presbensis $(\mathrm{P} 1)$ also represents a central haplotype within this taxon. It is only shared by specimens from Lake Prespa and the small neighbouring Lake Mikri Prespa (Fig. 2). Lake Prespa has a much higher total number of private haplotypes (Fig. 1) and as most of these haplotypes are derived from the putative ancestral haplotype P1, Lake Prespa appears to be the ancestral area for all extant haplotypes of $D$. presbensis. For D. blanci, the inferred ancestral haplotype is haplotype B1 (Fig. 2). As Lake Trichonis is the only natural lake in which this haplotype was found during our survey (accept for a single specimen in Lake Prespa), and as this lake shows the highest percentage of private D. blanci haplotypes (Fig. 1), it is assumed to be the ancestral area for the extant diversity of D. blanci.

\subsection{Test for genetic structure}

We performed two AMOVAs, corresponding to the two major sub-networks obtained in the first network analysis (see Fig. 2): D. presbensis + "D. stankovici" and D. blanci. The first analysis revealed a significant level of genetic differentiation between $D$. presbensis and " $D$. stankovici" with $33.45 \%$ of the total variation being distributed between these two groups $\left(F_{\mathrm{CT}}=0.3345, p<0.05\right)$. Variation among populations within groups accounted for $20.45 \%$ of total variation $\left(F_{\mathrm{SC}}=0.3073, p<0.001\right)$ and variation within populations for $46.10 \%$ of total variation $\left(F_{\mathrm{ST}}=0.5390, p<0.001\right)$.

The alternative exact test of sample differentiation based on haplotype frequencies also rejected the global null hypothesis of panmixia of $D$. presbensis and "D. stankovici" from a total of 9 water bodies $(p<0.001)$. Whereas a pairwise comparison of lakes did not indicate significant differences in the genetic structure of " $D$. stankovici" (i.e. between lakes Ohrid and Skutari; $p=0.106$ ), the differentiation
Table 4. Results of the exact test for significant pairwise genetic differences (level 0.05) in Dreissena blanci from different water bodies. Note that lakes Prespa and Pamvotis were excluded from the analysis as only a single specimen each was sampled in these lakes.

\begin{tabular}{|c|c|c|c|c|}
\hline & $\begin{array}{c}\text { Lake } \\
\text { Trichonis }\end{array}$ & $\begin{array}{c}\text { Lake } \\
\text { Amvrakia }\end{array}$ & $\begin{array}{l}\text { Kastrakiou } \\
\text { Reservoir }\end{array}$ & $\begin{array}{c}\text { Stratos } \\
\text { Reservoir }\end{array}$ \\
\hline \multicolumn{5}{|l|}{ Lake Trichonis } \\
\hline Lake Amvrakia & + & & & \\
\hline $\begin{array}{l}\text { Kastrakiou } \\
\text { Reservoir }\end{array}$ & + & + & & \\
\hline $\begin{array}{l}\text { Stratos } \\
\text { Reservoir }\end{array}$ & + & + & + & \\
\hline $\begin{array}{l}\text { Aliakmonas } \\
\text { Reservoir }\end{array}$ & - & + & + & + \\
\hline
\end{tabular}

between water bodies harbouring specimens of $D$. presbensis was significant in 19 out of 21 pairwise comparisons (Table 3).

The analysis of $D$. blanci indicated that in this taxon, variance among populations accounted for $24.02 \%$ of total variation and variation within populations for $75.98 \%$ $\left(F_{\mathrm{ST}}=0.2402, p<0.001\right)$. Following the qualitative guidelines of Wright (1978), this fixation index indicates high genetic differentiation. Note that among-group-variation is not applicable as this analysis involved only a single taxon.

The exact test of sample differentiation based on haplotype frequencies also rejected the global null hypothesis of panmixia of $D$. blanci from a total of 7 water bodies studied $(p<0.001)$. Pairwise analyses of individual lake systems indicated significant differences in 9 out of 10 comparisons (Table 4).

\subsection{Tests for neutrality}

Tajima's $D$ test of selective neutrality showed a significant deviation from the neutral mutation hypothesis in all three taxa (D. presbensis: $D=-2.43, p<0.001$; "D. stankovici": $D=-2.42, p<0.001 ; D$. blanci: $D=-1.54, p=0.025)$, indicating population size expansion and/or positive selection.

\subsection{Testing models of demographic and spatial expansions}

All individual mismatch analyses (Fig. 3) showed a unimodal distribution of pairwise nucleotide differences (also see the corresponding low raggedness values in Table 5, which are all non-significant). In addition, all sum of squared deviation (SSD) values (Table 5) are very low as well, none of them being significant. These data indicate that neither the pure demographic expansion model for lakes Ohrid, Prespa and Trichonis, nor the spatial expansion model for "D. stankovici", 

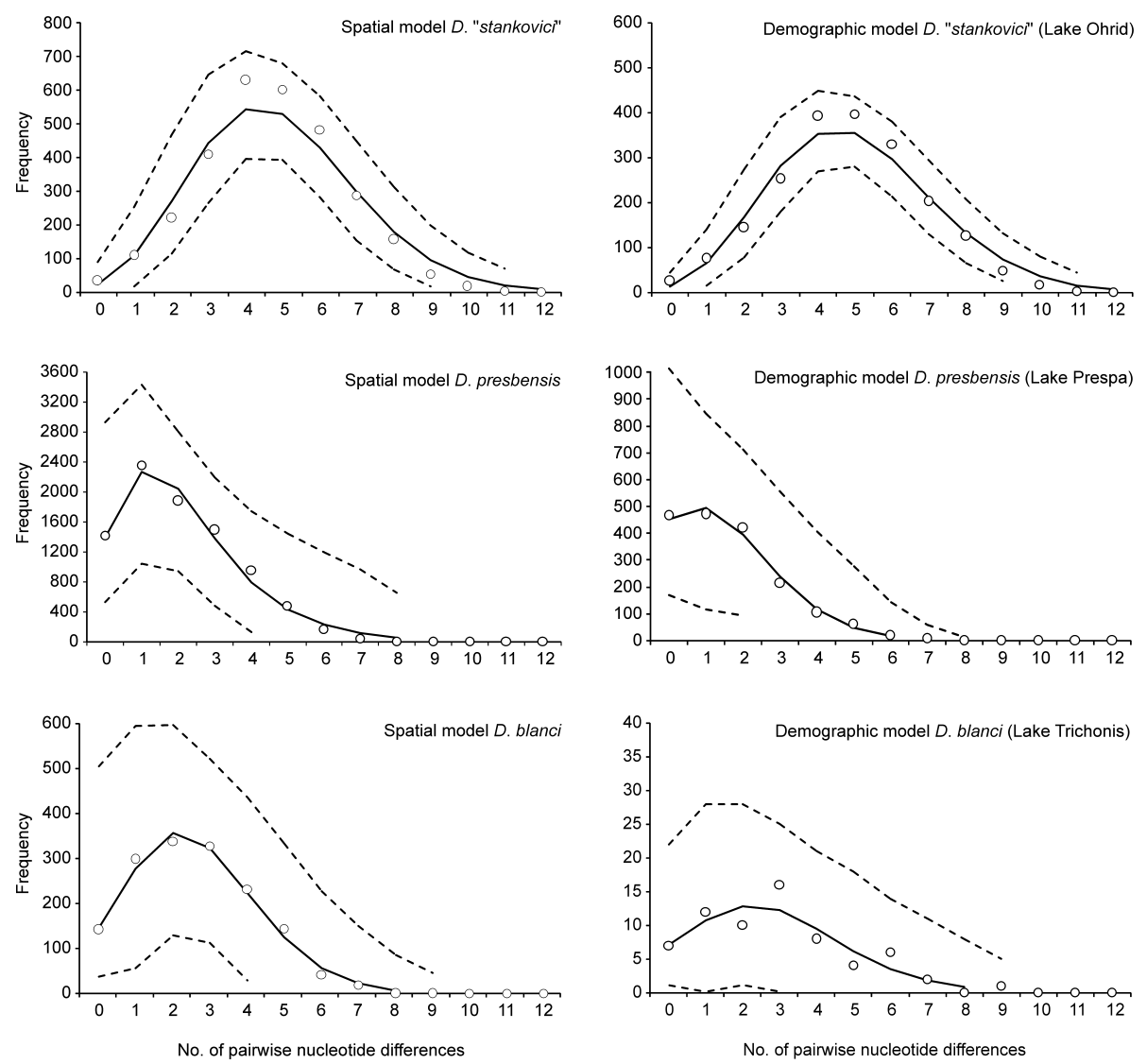

Fig. 3. Mismatch distribution of native Dreissena spp. based on COI mtDNA data. The distributions of pairwise nucleotide differences (circles) were tested against two expansion models (black lines): spatial expansion for all lakes (to the left) and demographic expansion out of the respective ancestral water body (to the right; see Result section for details). The $95 \%$ confidence intervals of the coalescent simulations are indicated by dashed lines.

D. presbensis, and D. blanci are rejected in favour of a demographic equilibrium.

\subsection{Estimation of time since population expansion}

The mean time estimates for the beginning of spatial/demographic expansion in "D. stankovici", D. presbensis, and D. blanci are given in Table 5. The demographic expansion of "D. stankovici" in Lake Ohrid and its spatial expansion into Lake Skutari started some 320 000-300 000 years ago and therefore considerably earlier than the demographic expansion of $D$. presbensis within Lake Prespa and its spatial expansion into nearby water bodies some 110000 and 70000 years ago, respectively (also see the nonoverlapping CI's in Table 5). The demographic expansion of D. blanci and its spatial expansion out of Lake Trichonis (160000 and 140000 years ago, respectively) apparently started before the spread of $D$. presbensis, but considerably later than the expansions of "D. stankovici" (CI's, however, are overlapping). The spatial expansion of D. presbensis out of Lake Prespa appeared to have started considerably later than its demographic expansion (but CI's overlap).
It should be noted that the onsets of population expansions inferred here for Dreissena spp. are independent of the age of the respective most recent common ancestors (MRCA). The age of the MRCA in all three taxa may be considerably higher than the inferred age of spatial expansion.

\section{Discussion}

\subsection{Biogeographical zones on the southern Balkans}

The biogeographical zonation of Dreissena spp. here inferred by molecular data largely corresponds with the zonations proposed previously based on data from fish. Dreissena "stankovici" occurs exclusively in the ecoregion "southeastern Adriatic drainages" (Fig. 1), D. blanci mainly in the ecoregion "Ionian drainages", and D. presbensis mainly in the Vardar and Thrace ecoregions. There is, however, considerable disagreement regarding the assignment of the ancient lakes Ohrid and Prespa to ecoregions. Most researchers consider Lake Ohrid as belonging to the southeastern Adriatic drainages (see Introduction, also see Albrecht and Wilke, 
Table 5. Estimated parameters of spatial and demographic expansion models in native Dreissena spp. based on mismatch analyses. For details on the estimation of time since expansion and its confidence intervals see the Method section. SSD: sum of squared deviations from the respective model; $p$ : significance of the respective parameter; RI: raggedness index; $\tau$ : population parameter Tau; CI: $95 \%$ confidence interval; $T$ : time since population expansion.

\begin{tabular}{|c|c|c|c|c|c|c|}
\hline & \multicolumn{3}{|c|}{ Spatial expansion model } & \multicolumn{3}{|c|}{ Demographic expansion model } \\
\hline & $\begin{array}{c}\text { "D. stankovici" } \\
\text { (all sites) }\end{array}$ & $\begin{array}{l}\text { D. presbensis } \\
\text { (all sites) }\end{array}$ & $\begin{array}{l}\text { D. blanci } \\
\text { (all sites) }\end{array}$ & $\begin{array}{l}\text { "D. stankovici" } \\
\text { (Lake Ohrid) }\end{array}$ & $\begin{array}{l}\text { D. presbensis } \\
\text { (Lake Prespa) }\end{array}$ & $\begin{array}{c}\text { D. blanci } \\
\text { (Lake Trichonis) }\end{array}$ \\
\hline $\operatorname{SSD}(p$-value $)$ & $0.001(0.53)$ & $0.001(0.60)$ & $0.001(0.80)$ & $0.002(0.26)$ & $0.001(0.95)$ & $0.009(0.73)$ \\
\hline $\mathrm{RI}(p$-value $)$ & $0.016(0.61)$ & $0.024(0.80)$ & $0.019(0.88)$ & $0.018(0.28)$ & $0.019(0.98)$ & $0.039(0.80)$ \\
\hline$\tau$ & 4.63 & 1.12 & 2.24 & 5.02 & 1.76 & 2.48 \\
\hline (CI) & $(2.96-5.12)$ & $(0.69-3.16)$ & $(1.29-3.68)$ & $(4.18-5.70)$ & $(0.43-3.80)$ & $(1.05-5.83)$ \\
\hline$T$ in Mya & 0.297 & 0.072 & 0.144 & 0.322 & 0.113 & 0.160 \\
\hline (CI) & $(0.201-0.393)$ & $(0-0.153)$ & $(0.061-0.227)$ & $(0.236-0.409)$ & $(0.002-0.224)$ & $(0.002-0.317)$ \\
\hline
\end{tabular}

2008). Some researchers noted a relationship to the Ionian region (e.g. Wilke et al., 2007), yet other researchers point to the high degree of isolation and faunal distinctness of Lake Ohrid faunal elements, which possibly warrants the assignment to its own region (e.g. Banarescu, 1991; Albrecht et al., 2009; Hauffe et al., 2010; Trajanovski et al., 2010). The data presented here, indeed, indicate a close relationship of Lake Ohrid specimens and the ecoregion "southeastern Adriatic drainages", demonstrated by the occurrence of "D. stankovici" in Lake Skutari. However, as the latter lake is almost directly connected to Lake Ohrid via the Drim River, the relatively isolated occurrence of "D. stankovici" in the Skutari area should not be overrated.

The situation for Lake Prespa is less ambiguous. Whereas most researchers consider this lake to be closely related to Lake Ohrid biogeographically, recent studies (e.g. Albrecht and Wilke, 2008; Albrecht et al., 2009) suggest a closer biogeographical connection between Lake Prespa and the lakes of the Vardar region. This pattern is also supported by the genetic analyses presented here. We therefore suggest modifying the borders of the Vardar ecoregion to include lakes Prespa and Mikri Prespa (also see Marková et al., 2010).

\subsection{Demographic changes in Dreissena spp. relative to environmental changes}

Whereas the distribution of groups of species among ecoregions often reflects the general biogeographical history of a larger area, a comparison of closely related taxa may reveal the effects of small-scale biotic and abiotic factors in space and time.

Estimates of the dates of population changes indicate that the onsets of demographic and spatial expansions in the three native taxa do not coincide, but differ considerably. This raises the question as to whether environmental changes (e.g. recovery from catastrophic lake-level low stands; Sturmbauer et al., 2001; Schultheiß et al., 2009) may have triggered population expansions, and if so, whether these changes were of global, regional, or local nature. Acknowledging that these different spatial scales may not be mutually exclusive, the disconcordance of demographic events in the taxa studied might, at first sight, point to local effects influencing individual lakes and their respective species. The situation, however, appears to be more complex because different lakes with different limnological characteristics (e.g. size, depth, source of water, residence time of water; also see Table 2) may buffer environmental changes to different degrees.

We are unable to provide explanations for the population expansions in "D. stankovici" some 300000-320000 years ago and in D. blanci some 140000 years ago due to lack of relevant paleolimnological data.The demographic expansion of $D$. presbensis in Lake Prespa some 110000 years ago, however, can possibly be linked to environmental and climatic fluctuations that were inferred for the Ohrid-Prespa region during the last glacial-interglacial cycle (Lindhorst et al., 2010; Vogel et al., 2010a,b; Wagner et al., 2010). The Eemian interglacial ended approximately 110000 years ago and was characterized by abrupt climatic changes and significant lake level fluctuations (Lézine et al., 2010), which might have caused the demographic expansion observed. Interestingly, while these affects are apparent in Lake Prespa, they did not leave traces in the demographic history of "D. stankovici" in Lake Ohrid. In fact, a recent study shows that "D. stankovici" already had a dominant position in the benthic invertebrate assemblages of the latter lake during the Last Interglacial (Albrecht et al., 2010). These observations lead to the hypothesis that regional environmental changes may have had pronounced effects on the population histories of Dreissena spp. in the Balkans, though the high buffer capacity of, for example, Lake Ohrid (deep oligotrophic lake with a considerable water input coming from sublacustrine springs) may have mitigated these effects (but see Reed et al., 2010 for the sensitivity of diatoms to climate change in 
Lake Ohrid). Thus, the onset of spatial expansion in D. presbensis out of Lake Prespa may be associated with a recovery from lake level low stands, whereas we do not see such effects in Lake Ohrid populations. Nonetheless, given the patchy distribution of lakes in the area, local events affecting individual lakes probably had pronounced effects on the respective demographic histories of Dreissena spp. as well. In fact, both the exact test of sample differentiation and the AMOVA reject panmixia within the three native taxa studied. The high degree of genetic structure in all these taxa is rather unexpected. Most water bodies studied here are frequently used by migratory water birds as breeding or resting grounds (e.g. Grimmett and Jones, 1989). Together with the, in part, low geographical distance between these water bodies, one would expect a high degree of passive dispersal and therefore considerable gene flow between lakes and reservoir. However, the AMOVAs indicate significant pairwise genetic differences among $D$. presbensis populations from different water bodies, except for lakes Pamvotis, Dojran and the Aliakmonas Reservoir (Table 3). The same is true for D. blanci. Within this taxon, populations from different water bodies show a high degree of pairwise differentiation except for those inhabiting the Aliakmonas Reservoir and Lake Trichonis (Table 4). While both taxa have a relatively high number of private haplotypes in natural lakes (particularly in ancient lakes), we only see a clear geographical structure in D. presbensis (Fig. 2). Most specimens from lakes Prespa and Mikri Prespa form one group, specimens from the remote Lake Pamvotis form a second group, and most specimens from the eastern lakes and reservoirs (Vegoritis, Dojran, Volvi, Aliakmonas) form a third group. The difference in geographical structure between $D$. presbensis and $D$. blanci could, however, be simply the result of an isolation-by-distance effect as $D$. blanci has a much smaller range than $D$. presbensis (see Fig. 1).

\subsection{Faunal exchange and eco-insularity of ancient lakes in space and time}

While isolation-by-distance may explain some of the patterns observed in our data set, it does not explain the lack of faunal overlap between lakes Prespa and Ohrid. Although haplotypes of "D. stankovici" and D. presbensis differ by as little as one mutational step (see Fig. 2), these sister-lakes do not share haplotypes nor do individual haplotypes from Lake Ohrid cluster together with those from Lake Prespa. The high degree of population distinctiveness in ancient lakes also becomes evident when looking at the distribution of haplotypes (particularly private haplotypes) among water bodies. The highest haplotype diversities and the highest percentage of private haplotypes (see Fig. 1) are to be found in (i) Lake Ohrid, (ii) Lake Prespa, and (iii) Lake Trichonis. Interestingly these lakes also appear to be, possibly in the same order, the oldest lakes in the Balkans (e.g. Albrecht and Wilke,
2008; Albrecht et al., 2009). Acknowledging that we are unable to provide a quantifiable neutral model of private haplotype diversities in the lakes studied, we do see a general trend that shows an increase of haplotype diversities from artificial and relatively young natural lakes over potential ancient lakes to well recognized ancient lakes, such as Lake Ohrid. In other words, the degree of eco-insularity may be related to the age of the respective water body and it is conceivable that species in those lakes, characterized by long demographic histories, are better adapted to the individual settings of ancient lakes and that they are therefore typically able to out-compete immigrants originating from other water bodies (e.g. Boss, 1978; Radoman, 1985; Albrecht and Wilke, 2008). Moreover, it has recently been shown for the Neogene lakes in the Balkans that, once a fauna evolved in situ, inter-lake exchange remains extremely rare (Harzhauser and Mandic, 2008). Of course, isolation (and therefore the frequency of emigration and immigration events) also plays an important role for eco-insularity. Long-lived lakes (ancient lakes and paleolakes) have repeatedly been regarded as islands with observed patterns being discussed in an islandbiogeographic context (e.g. Wesselingh, 2007).

We do not know the processes leading to the relative high degree of eco-insularity of Dreissena spp. in ancient lakes in the Balkans but empirical evidence from aquarium experiments (Wilke et al., unpublished data) also indicate that "D. stankovici" from Lake Ohrid is very difficult to maintain outside its native environment. This double-sided effect of eco-insularity - endemic organisms may outcompete most invading species but are probably inferior outside their native water bodies - may have considerable implications for the protection of native Dreissena spp. on the Balkans. As shown by Kostoski et al. (2010), Lake Ohrid harbours an increasing number of invasive species. These species are mainly to be found in environmentally disturbed areas such as the euthrophicated Ohrid Bay on the Macedonian side and the Lin Peninsula on the Albanian side (also see Matzinger et al., 2007). There, water conditions might have changed in such a way that endemic species lose their competitive advantage. These are therefore the areas specimens from outside could populate most easily and from where a displacement of native populations could start. The first confirmed record of D. polymorpha in the southwestern Balkans presented here originated from such a disturbed system - from Lake Saško in the Skutari drainage.

Our data also indicate that immigration and emigration of Dreissena specimens may occur on a regular basis in the Balkans. This becomes evident not only from specimens found in relatively young artificial water bodies such as the Aliakmonas, Kastrakiou and Stratos reservoirs (Fig. 1), but also from the low-frequency-occurrence of D. blanci specimens in lakes Pamvotis and Prespa. Such dispersal events may result in small isolated subpopulations subject to severe bottle necks and subsequent genetic drift (Wright, 1931; Wilke et al., 2010). These processes could, at least partly, 
explain the patterns of extant Dreissena biodiversity seen in the Balkans.

\subsection{Evolutionary history of native Dreissena spp. in the Balkans}

Given that native Dreissena spp. from the Balkans form a monophyletic group as suggested by Albrecht et al. (2007), and considering their demographic histories and patterns of haplotype diversity inferred in the present paper, we suggest that an ancestral Dreissena population in Lake Ohrid may be the source of today's Dreissena biodiversity in the area.

Specimens of this population possibly invaded lakes in the southern Ionian region, such as Lake Trichonis, and became reproductively isolated (extant $D$. blanci). Independent of this event, and probably at a later point in time, specimens of the ancestral source population also invaded Lake Prespa (extant $D$. presbensis). After a major demographic expansion, Lake Prespa then probably became the source for the spreading of $D$. presbensis to lakes in the Vardar and Thrace regions. Given the close haplotype relationship between $D$. presbensis from lakes Prespa and Pamvotis (see, for example, the shared haplotype P5 in Fig. 2), Lake Prespa possibly was the source for $D$. presbensis specimens in Lake Pamvotis (Ionian region) as well.

Interestingly, there also has been a spread of specimens of " $D$. stankovici" from Lake Ohrid into the Skutari system. This is, however, not surprising as the only outflow of Lake Ohrid, the Drim River (see Fig. 1), runs along Lake Skutari. In fact, a similar "out of Ohrid" event has been noted by Wilke et al. (2007). In their paper, the authors presented data suggesting that the ancestor of the pyrgulinid gastropod species Pyrgula annulata, which today occurs in some Italian lakes, in Croatia and also in Lake Skutari, probably inhabited Lake Ohrid. Studies of the endemic cypriniform fish fauna also suggest a closely interlinked Ohrid-Drim-Skutari system (Šanda, 2007; Talevski et al., 2009; Marková et al., 2010).

The patterns of (limited) immigration and emigration observed here may help to provide a hypothesis for the high degree of freshwater biodiversity in the Balkans not only for Dreissena spp., but also for other invertebrate taxa. We suggest that during an early limnological phase (or after catastrophic limnological events), a patchy system of ancient lakes in the area with limited gene flow supported the survival of small isolated subpopulations. Probably during a later phase, eco-insularity of lake faunas prevented excessive hybridization and sympatry of closely related taxa. Future studies focusing on processes such as selection vs. drift based on additional nuclear markers may help to test this hypothesis.

\subsection{Potential of native Dreissena spp. in the Balkans for becoming invasive}

Given that the two well-known invasive Dreissena taxa, D. polymorpha and D. rostriformis bugensis probably started their massive spread in western Europe and North America from small isolated areas and that the native Dreissena species in the Balkans are now known to occur in many more water bodies than previously believed, there is real concern that one or more of these native taxa could become invasive (see Albrecht et al., 2007). The data presented here, however, indicate that their spatial expansion had already started between approximately 70000 and 300000 years ago and therefore is not human-mediated. Moreover, all species still appear to be restricted to their native ranges. Of concern, however, is that today two taxa, D. presbensis and D. blanci, also occur in artificial water bodies. While many reservoirs in the area are still free of Dreissena spp. (see the negative records in Fig. 1), we did find specimens in large numbers in at least three major reservoirs situated in two ecoregions. We therefore urgently suggest a monitoring program for Dreissena spp. in artificial lakes in the area as an early warning system. At the same time, studies are necessary to investigate whether invasive $D$. polymorpha show signs of further range expansions into areas currently exclusively populated by native Dreissena taxa in the Balkans.

Acknowledgements. We are very grateful to Peter Glöer (Hetlingen) and Vladimir Pešić (Podgorica), who provided Dreissena materials from Lake Skutari. We also thank Athanasios Mogias (Democritus University of Thrace), who helped to prepare our field work in Greece and arranged for the necessary collecting permits. Silvia Nachtigall and Kirstin Schreiber (Justus Liebig University Giessen) are acknowledged for their help with the DNA work. Special thanks go to Torsten Hauffe and Kirstin Schreiber (Justus Liebig University Giessen) for collecting specimens of D. polymorpha in the vicinity of Lake Skutari. Two anonymous referees are acknowledged for reviewing the manuscript. The work was supported by German Research Foundation grants WI1901/8-1 and AL 1076/3-1 to TW and CA.

Edited by: B. Wagner

\section{References}

Abell, R., Thieme, M. L., Revenga, C., Bryer, M., Kottelat, M., Bogutskaya, N., Coad, B., Mandrak, N., Contreras Balderas, S., Bussing, W., Stiassny, M. L. J., Skelton, P., Allen, G. R., Unmack, P., Naseka, A., Ng, R., Sindorf, N., Robertson, J., Armijo, E., Higgins, J. V., Heibel, T. J., Wikramanayake, E., Olson, D., López, H., Reis, R. E., Lundberg, J. G., Sabaj Pérez, M. H., and Petry, P.: Freshwater ecoregions of the world: a new map of biogeographic units for freshwater biodiversity conservation, Bioscience, 58, 403-414, 2008.

Albrecht, C., Hauffe, T., Schreiber, K., and Wilke, T.: Mollusc biodiversity and endemism in the putative ancient Lake Trichonis (Greece), Malacologia, 51, 357-375, 2009.

Albrecht, C., Schultheiß, R., Kevrekidis, T., Streit, B., and Wilke, T.: Invaders or endemics? Molecular phylogenetics, biogeography and systematics of Dreissena in the Balkans, Freshwater Biol., 52, 1525-1536, 2007. 
Albrecht, C., Trajanovski, S., Kuhn, K., Streit, B., and Wilke, T.: Rapid evolution of an ancient lake species flock: freshwater limpets (Gastropoda: Ancylidae) in the Balkan lake Ohrid, Org.s Divers. Evol., 6, 294-307, 2006.

Albrecht, C. and Wilke, T.: Lake Ohrid: biodiversity and evolution, Hydrobiologia, 615, 103-140, 2008.

Albrecht, C., Wolff, C., Glöer, P., and Wilke, T.: Concurrent evolution of ancient sister lakes and sister species: The freshwater gastropod genus Radix in lakes Ohrid and Prespa, Hydrobiologia, 615, 157-167, 2008.

Albrecht, C., Vogel, H., Hauffe, T., and Wilke, T.: Sediment core fossils in ancient Lake Ohrid: testing for faunal change in molluscs since the Last Interglacial period, Biogeosciences Discuss., 7, 3969-3999, doi:10.5194/bgd-7-3969-2010, 2010.

Banarescu, P. M.: Zoogeography of fresh waters, Vol. 2: Distribution and dispersal of freshwater animals in North America and Eurasia, Aula Verlag, Wiesbaden, 1991.

Banarescu, P. M.: Distribution pattern of the aquatic fauna of the Balkan Peninsula, in: Balkan biodiversity. Pattern and process in the European hotspot, edited by: Griffiths, H. I., Kryśtufek, B., and Reed, J. M., Kluwer Academic Publishers, Dordrecht, Boston, London, 203-217, 2004.

Bank, R. A.: Towards a catalogue and bibliography of the freshwater Mollusca of Greece, Heldia, 6, 51-86, 2006.

Boss, K. J.: On the evolution of gastropods in ancient lakes, in: Pulmonates: Systematics, Evolution and Ecology, Vol. 2a., edited by: Fretter, V. and Peake, J., Academic Press, London, New York, San Francisco, 385-428, 1978.

Clement, M., Posada, D., and Crandall, K. A.: TCS: a computer program to estimate gene genealogies, Mol. Ecol., 9, 1657-1659, 2000.

Denèfle, M., Lézine, A.-M., Fouache, E., and Dufaure, J.-J.: 12,000-year pollen record from Lake Maliq, Albania, Quaternary Res., 54, 423-432, 2000.

Excoffier, L.: Patterns of DNA sequence diversity and genetic structure after a range expansion: Lessons from the infinite-island model, Mol. Ecol., 13, 853-864, 2004.

Excoffier, L., Laval, G., and Schneider, S.: Arlequin (version 3.0): An integrated software package for population genetics data analysis, Evol. Bioinform., 1, 47-50, 2005.

Folmer, O., Black, M., Hoeh, W., Lutz, R. A., and Vrijenhoek, R. C.: DNA primers for amplification of mitochondrial cytochrome $\mathrm{c}$ oxidase subunit I from diverse metazoan invertebrates, Mol. Mar. Biol. Biotech., 3, 294-299, 1994.

Frogley, M. R. and Preece, R. C.: A faunistic review of the modern and fossil molluscan fauna from lake Pamvotis, Ioannina, an ancient lake in NW Greece: implications for endemism in the Balkans, in: Balkan biodiversity, Pattern and process in the European hotspot, edited by: Griffiths, H. I., Kryśtufek, B., and Reed, J. M., Kluwer Academic Publishers, Dordrecht, Boston, London, 243-260, 2004.

Gelembiuk, G. W., May, G. E., and Lee, C. E.: Phylogeography and systematics of zebra mussels and related species, Mol. Ecol., 15, 1021-1031, 2006.

Griffiths, H. I. and Frogley, M. R.: Fossil ostracods, faunistics and the evolution of regional biodiversity, in: Balkan biodiversity, Pattern and process in the European hotspot, edited by: Griffiths, H. I., Kryśtufek, B., and Reed, J. M., Kluwer Academic Publishers, Dordrecht, Boston, London, 261-272, 2004.
Griffiths, H. I., Reed, J. M., Leng, M. J., Ryan, S., and Petkovski, S.: The conservation status and recent palaeoecology of Balkan Lake Dojran, Biol. Conserv., 104, 35-49, 2002.

Griffiths, H. I., Kryśtufek, B., and Reed, J. M.: Balkan biodiversity, Pattern and process in the European hotspot, Kluwer Academic Publishers, Dordrecht, Boston, London, 2004.

Grimmett, R. F. A. and Jones, T. A.: Important bird areas in Europe, ICBP technical publication Vol. 9, International Council for Bird Preservation Technical Publication, 1989.

Hall, T. A.: BioEdit: a user-friendly biological sequence alignment editor and analysis program for Windows 95/98/NT, Nucl. Acid. S., 41, 95-98, 1999.

Harzhauser, M. and Mandic, O.: Neogene lake systems of Central and South-Eastern Europe: Faunal diversity, gradients and interrelations, Palaeogeogr. Palaeoclimatol. Palaeoecol., 260, 417434, 2008.

Hauffe, T., Albrecht, C., Schreiber, K., Birkhofer, K., Trajanovski, S., and Wilke, T.: Spatially explicit analyses of gastropod biodiversity in ancient Lake Ohrid, Biogeosciences Discuss., 7, 49534985, doi:10.5194/bgd-7-4953-2010, 2010.

Hauswald, A.-K., Albrecht, C., and Wilke, T.: Testing two contrasting evolutionary patterns in ancient lakes: species flock vs. species scatter in valvatid gastropods of Lake Ohrid, Hydrobiologia, 615, 169-179, 2008.

Karaman, G. and Beeton, A.:The biota and limnology of Lake Skadar, Univerzitet "VeljkoVlahovic", Titograd \& Milwaukee, 468 pp., 1981.

Kinzelbach, R.: The main features of the phylogeny and dispersal of the Zebra Mussel Dreissena polymorpha, in: The Zebra Mussel Dreissena polymorpha, edited by: Neumann, D. and Jenner, H. A., Gustav Fischer Verlag, New York, 5-17, 1992.

Korniushin, A. V.: The bivalve mollusc fauna of ancient lakes in the context of the historical biogeography of the Balkan region, in: Balkan biodiversity, Pattern and process in the European hotspot, edited by: Griffiths, H. I., Krytufek, B., and Reed, J. M., Kluwer Academic Publishers, Dordrecht, Boston, London, 219-241, 2004.

Kostoski, G., Albrecht, C., Trajanovski, S., and Wilke, T.: A freshwater biodiversity hotspot under pressure - assessing threats and identifying conservation needs for ancient Lake Ohrid, Biogeosciences Discuss., 7, 5347-5382, doi:10.5194/bgd-7-5347-2010, 2010.

Lézine, A.-M., von Grafenstein, U., Andersen, N., Belmecheri, S., Bordon, A., Caron, B., Cazet, J.-P., Erlenkeuser, H., Fouache, E., Grenier, C., Huntsman-Mapila, P., Hureau-Mazaudier, D., Manelli, D., Mazaud, A., Robert, C., Sulpizio, R., Tiercelin, J.-J., Zanchetta, G., and Zeqollari, Z.: Lake Ohrid, Albania, provides an exceptional multi-proxy record of environmental changes during the last glacial-interglacial cycle, Palaeogeogr. Palaeoclimatol. Palaeoecol., 287, 116-127, 2010.

Lindhorst, K., Vogel, H., Krastel, S., Wagner, B., Hilgers, A., Zander, A., Schwenk, T., Wessels, M., and Daut, G.: Stratigraphic analysis of lake level fluctuations in Lake Ohrid: an integration of high resolution hydro-acoustic data and sediment cores, Biogeosciences Discuss., 7, 3651-3689, doi:10.5194/bgd-7-3651-2010, 2010.

Lipej, L. and Dulčić, J.: The current status of Adriatic fish biodiversity, in: Balkan biodiversity. Pattern and process in the European hotspot, edited by: Griffiths, H. I., Kryśtufek, B., and Reed, J. 
M., Kluwer Academic Publishers, Dordrecht, Boston, London, 291-306, 2004.

Marková, S., Šanda, R., Crivelli, A., Shumka, S., Wilson, I. F., Vukić, J., Berrebi, P., and Kotlík, P.: Nuclear and mitochondrial DNA sequence data reveal the evolutionary history of Barbus (Cyprinidae) in the ancient lake systems of the Balkans, Mol. Phyl. Evol., 55, 488-500, 2010.

Martens, K.: Speciation in ancient lakes (review), Trends Ecol. Evol., 12, 177-182, 1997.

Matzinger, A., Schmid, M., Veljanoska-Sarafiloska, E., Patceva, S., Guseska, D., Wagner, B., Müller, B., Sturm, M., and Wüest, A.: Eutrophication of ancient Lake Ohrid: Global warming amplifies detrimental effects of increased nutrient inputs, Limnol. Oceanogr., 52, 338-353, 2007.

May, G. E., Gelembiuk, G. W., Panov, V. E., Orlova, M. I., and Lee, C. E.: Molecular ecology of zebra mussel invasions, Mol. Ecol., 15, 1021-1031, 2006.

May, B. and Marsden, J. E.: Genetic identification and implications of another invasive species of dreissenid mussel in the Great Lakes, Can. J. Fish. Aquat. Sci., 49, 1501-1506, 1992.

Molloy, D. P., Giamberini, L., Burlakova, L. E., Karatayev, A. Y., Cryan, J. R., Trajanovski, S. L., and Trajanovska, S. P.: Investigation of the endosymbionts of Dreissena stankovici with morphological and molecular confirmation of host species, in: The Zebra Mussel in Europe, edited by: van der Velde, G., Rajagopal, S., and bij de Vaate, A., Backhuys Publishers, Leiden, The Netherlands, 227-237, 2010.

Molloy, D. P., de Vaate, A., Wilke, T., and Giamberini, L.: Discovery of Dreissena rostriformis bugensis (Andrusov 1897) in Western Europe, Biol. Invasions, 9, 871-874, 2007.

Nalepa, T. F. and Schloesser, D. W.: Zebra Mussels: Biology, impact, and control, Lewis Press, Boca Raton, 1993.

Pfenninger, M. and Posada, D.: Phylogeographic history of the land snail Candidula unifasciata (Helicellinae, Stylommatophora): Fragmentation, corridor migration, and secondary contact, Evolution, 56, 1776-1788, 2002.

Radoman, P.: Hydrobioidea, a superfamily of Prosobranchia, Faculty of Science - Department of Biology, Beograd, 1985.

Raymond, M. and Rousset, F.: An exact test for population differentiation, Evolution, 49, 1280-1283, 1995.

Reed, J. M.: The potential of diatoms as biodiversity indicators in the Balkans, in: Balkan biodiversity, Pattern and process in the European hotspot, edited by: Griffiths, H. I., Kryśtufek, B., and Reed, J. M., Kluwer Academic Publishers, Dordrecht, Boston, London, 273-289, 2004.

Reed, J. M., Cvetkoska, A., Levkov, Z., Vogel, H., and Wagner, B.: The last glacial-interglacial cycle in Lake Ohrid (Macedonia/Albania): testing diatom response to climate, Biogeosciences Discuss., 7, 4689-4714, doi:10.5194/bgd-7-4689-2010, 2010.

Rogers, A. R. and Harpending, H.: Population growth makes waves in the distribution of pairwise genetic differences, Mol. Biol. Evol., 9, 552-569, 1992.

Royal Haskoning: Lake Shkoder transboundary diagnostics analysis - Albania \& Montenegro, GEF project: "The Lake Shkoder integrated ecosystem management project" (Project number 9P6515), World Bank (IBRD), Washington, DC, 2006.

Šanda, R.: Endemism of cypriniform fishes of Lakes Ohrid and Prespa: a review, 1st symposium for protection of natural lakes in Republic of Macedonia, Ohrid, 40, 2007.
Schneider, S. and Excoffier, L.: Estimation of past demographic parameters from the distribution of pairwise differences when the mutation rates vary among sites: Application to human mitochondrial DNA, Genetics, 152, 1079-1089, 1999.

Schultheiß, R., Albrecht, C., Bößneck, U., and Wilke, T.: The neglected side of speciation in ancient lakes: phylogeography of an inconspicuous mollusc taxon in lakes Ohrid and Prespa, Hydrobiologia, 615, 141-156, 2008.

Schultheiß, R., Jørgensen, A., Wilke, T., and Albrecht, C.: The birth of an endemic species flock: demographic history of the Bellamya group (Gastropoda, Viviparidae) in Lake Malawi, Biol. J. Linn. Soc., in press, 2010.

Schultheiß, R., Van Bocxlaer, B., Wilke, T., and Albrecht, C.: Old fossils-young species: evolutionary history of an endemic gastropod assemblage in Lake Malawi, Proc. R. Soc. Lond. B, 276, 2837-2846, 2009.

Sell, J. and Spirkovski, Z.: Mitochondrial DNA differentiation between two forms of trout Salmoletnica, endemic to the Balkan Lake Ohrid, reflects their reproductive isolation, Mol. Ecol., 13, 3633-3644, 2004.

Stepien, C. A., Taylor, C. D., Grigorovich, I. A., Shirman, S. V., Wei, R., Korniushin, A. V., and Dabrowska, K. A.: DNA and systematic analysis of invasive and native dreissenid mussels: Is Dreissena bugensis really D. rostriformis?, Aquat. Invaders, 14, 8-18, 2003.

Strong, E. E., Gargominy, O., Ponder, W. F., and Bouchet, P.: Global diversity of gastropods (Gastropoda: Mollusca) in freshwater, Hydrobiologia, 595, 149-166, 2008.

Sturmbauer, C., Baric, S., Salzburger, W., Ruber, L., and Verheyen, E.: Lake level fluctuations synchronize genetic divergences of cichlid fishes in African lakes, Mol. Biol. Evol., 18, 144-154, 2001.

Tajima, F.: Statistical method for testing the neutral mutation hypothesis by DNA polymorphism, Genetics, 123, 585-595, 1989.

Talevski, T., Milosevic, D., Maric, D., Petrovic, D., Talevska, M., and Talevska, A.: Biodiversity of ichthyofauna from Lake Prespa, Lake Ohrid and Lake Skadar, Biotechnol. Biotec. Eq., 23, 400-404, 2009.

Trajanovski, S., Albrecht, C., Schreiber, K., Schultheiß, R., Stadler, T., Benke, M., and Wilke, T.: Testing the spatial and temporal framework of speciation in an ancient lake species flock: the leech genus Dina (Hirudinea: Erpobdellidae) in Lake Ohrid, Biogeosciences Discuss., 7, 5011-5045, doi:10.5194/bgd-7-50112010, 2010.

Tzedakis, P. C.: Museums and cradles of Mediterranean biodiversity, J. Biogeogr., 36, 1033-1034, 2009.

Vogel, H., Wagner, B., Zanchetta, G., Sulpizio, R., and Rosén, P.: A paleoclimate record with tephrochronological age control for the last glacial-interglacial cycle from Lake Ohrid, Albania and Macedonia, J. Paleolimnol., 44, 295-310, doi:10.1007/s10933009-9404-x, 2010a.

Vogel, H., Zanchetta, G., Sulpizio, R., Wagner, B., and Nowaczyk, N.: A tephrostratigraphic record for the last glacial-interglacial cycle from Lake Ohrid, Albania and Macedonia, J. Quat. Sci., 25, 320-338, doi:10.1002/jqs.1311, 2010b.

Wagner, B., Vogel, H., Zanchetta, G., and Sulpizio, R.: Environmental changes on the Balkans recorded in the sediments from lakes Prespa and Ohrid, Biogeosciences Discuss., 7, 3365-3392, doi:10.5194/bgd-7-3365-2010, 2010. 
Wesselingh, F. P.: Long-lived lake molluscs as island faunas: a bivalve perspective, in: Biogeography, time and place: distributions, barriers and islands, edited by: Renema, W., Springer Verlag, Dordrecht, 275-314, 2007.

Wilke, T., Albrecht, C., Anistratenko, V. V., Sahin, S. K., and Yildirim, M. Z.: Testing biogeographical hypotheses in space and time: Faunal relationships of the putative ancient lake Egirdir in Asia Minor, J. Biogeogr., 34, 1807-1821, 2007.

Wilke, T., Benke, M., Brändle, M., Albrecht, C., and Bichain, J.-M.: The neglected side of the coin: non-adaptive radiations in spring snails (Bythinella spp.), in: Evolution in action: Case studies in adaptive radiation, speciation and the origin of biodiversity, edited by: Glaubrecht, M., Springer Verlag, Dordrecht, 571-578, doi:10.1007/978-3-642-12425-9_25, 2010.

Wilke, T., Davis, G. M., Qiu, D., and Spear, R. C.: Extreme mitochondrial sequence diversity in the intermediate schistosomiasis host Oncomelania hupensis robertsoni: another case of ancestral polymorphism?, Malacologia, 48, 143-157, 2006.
Wilke, T., Schultheiß, R., and Albrecht, C.: As time goes by: A simple fool's guide to molecular clock approaches in invertebrates, From the symposium "Molluscs as models in evolutionary biology: from local speciation to global radiation" presented at the World Congress of Malacology, held from 15 to 20 July 2007 in Antwerp, Belgium, Am. Malacol. Bull., 27, 25-45, 2009.

Wright, S.: Statistical theory of evolution, Am. Stat. J., March Suppl., 201-208, 1931.

Wright, S.: Evolution and the Genetics of Populations, Volume 4: Variability within and among natural populations, University of Chicago Press, Chicago, 1978.

Wysocka, A., Kostoski, G., Kilikowska, A., Wróbel, B., and Sell, J.: The Proasellus (Crustacea, Isopoda) species group, endemic to the Balkan Lake Ohrid: a case of ecological diversification?, Fund. Appl. Limnol., 172, 301-313, 2008.

Zacharias, I., Bertachas, I., Skoulikidis, N., and Koussouris, T.: Greek lakes: Limnological overview, Lake Reserv. Manage., 7, 55-62, 2002. 